\title{
From Educational Government to the Government of Education: The Decline and Fall of the British Columbia Ministry of Education, 1972-1996 ${ }^{1}$
}

\author{
Thomas Fleming
}

The quarter of a century between 1972 and 1996 witnessed the end of the Imperial Age of school administration in British Columbia. The historical pattern of strong central control which had directed the course of provincial schooling for a century was beginning to unravel even before the 1960s were over, prompted in part by a malaise inside educational government and by new forces in and outside schools. Although provincial authorities entered the 1970s still confident in their capacity to control and direct public education, the Ministry of Education found itself before the decade ended, like Napoleon's army retreating from Moscow, bewildered by an unfamiliar landscape and harried on all sides by adversaries who seemed to materialize from nowhere, each with its own special brief for provincial schools. By the 1980s, the province's education bureaucracy, once the dominant and solitary voice in school affairs, was obliged to compete on the public policy stage with a chorus of others eager to contest the province's right to speak on behalf of children. By the mid-1990s, the rising power of the teachers' Federation, increasing parental and public demands for participation in educational decisions, and the Ministry of Education's ambiguity about its own purpose had all served, in various ways, to reduce the province's leadership in public education.

Le quart de siècle compris entre les années 1972 et 1996 témoigne de la fin de l'époque « impériale » de l'administration scolaire en Colombie-Britannique. Le modèle historique de l'autorité centrale forte, qui avait caractérisé la direction des programmes scolaires de la province depuis un siècle, avait commencé à s'effriter avant même la fin des années 1960, sous l'effet conjugué d'un malaise existant chez les autorités scolaires et de la présence de forces nouvelles tant à l'intérieur qu'à l'extérieur des écoles. Bien que les autorités provinciales entamèrent les années 1970 confiantes en leur capacité à contrôler et à diriger l'instruction publique, le ministre de l'Éducation se retrouva lui-même, avant la fin de la décennie, dans une situation analogue à la retraite des armées napoléoniennes devant Moscou : dérouté par un environnement inconnu et harcelé de tous côtés par des adversaires qui semblaient surgir de nulle part, chacun présentant son propre projet pour les écoles de la province. Vers les années 1980, l'administration scolaire provinciale, qui était auparavant la voix dominante et unique en matière scolaire, fut forcée à rivaliser avec une armée de groupes, impatients de contester le droit de la province de parler au nom des

1 This paper was presented as the keynote address to the 2002 British Columbia Ministry of Education Research Symposium at Simon Fraser Harbourside Centre, Vancouver, 23 March 2002.

(C)Historical Studies in Education / Revue d'histoire de l'éducation 15, 2 (2003): 210-36 
enfants. Au milieu des années 1990, le force montante de la Fédération des enseignants, les demandes croissantes des parents et de la population ainsi que les objectifs ambigus du ministre de l'Éducation avaient, de différentes manières, contribué à réduire l'autorité de la province dans le domaine de l'instruction publique.

The following discussion examines the changing character of the British Columbia Ministry of Education during the quarter of a century that began in 1972 and ended in 1996. More specifically, it explores the myriad social, political and economic forces that reshaped both the form and function of this government bureau during this period and how these forces served to change and, ultimately, diminish the pivotal role this branch of government historically played in developing and governing provincial schools since the establishment of the public education system in 1872.

\section{“A World in Itself"}

Public school history in British Columbia is, essentially, a history in two parts. From 1872, when public education was first organized, until 1972, when the Department of Education was on the eve of becoming a "ministry" of government, control of provincial schooling was highly centralized and virtually all major decisions about schools were made within the province's educational bureau on Victoria's Government Street. True to its nineteenth-century origins, British Columbia's school governance system was colonial in manner and imperial in character. The Education Office (after 1920 the Department of Education) functioned similarly to the colonial offices that governed the British Empire. The great educational dominion marked by provincial borders was divided into discrete territorial domains presided over by Her Majesty's school inspectors, who acted much like the British district commissioners who managed far-flung corners of the Empire. Like the Raj in India, it was a system of government in which information flowed upward from the field and decisions flowed downward from headquarters. Desk-bound in stately offices within the Legislative Buildings, the province's chief school officers operated the system by remote control, dispatching directives to inspectors who ensured that the province's will - in the form of rules, regulations, and curricular prescriptions - was closely followed in schools from the wind-swept coast across the Rocky Mountain trench into the grassy plains of the high plateau. 
In short, as the 1960s ended, the Department of Education, like the province, was "a world in itself” that had "not quite relinquished its old aspiration to be an Empire," to quote historian Margaret Ormsby. $^{2}$

After 1972, however, this completely centralized and generally sedate world of school administration disintegrated - corroded from within by the passing of old traditions and harassed from without by powerful new forces that radically challenged how schools were governed and administered. As political manifestations of colonialism came under attack around the world after 1945, so, too, did old colonial pattern of school governance. Strident new demands for political and personal freedoms, challenges to the established social order, and a generalized revolt against authority from family living rooms to state corridors produced a decade of social excitement and turbulence that surfaced in the early 1960s and ran through the early 1970s, transforming all manner of social, political, and educational institutions along the way. Dramatic growth in the under-30 population energized a many-sided movement for change that led by the late $1960 \mathrm{~s}$, if not to a social revolution, then at least to a cultural prison-break in which long-neglected constituencies, as well as new coalitions, clamoured for recognition of their rights and expression of these rights - in legislative provision of categorical programs and services in education as well as in other portfolios of government. The politics of identity had arrived and were about to be felt in one of society's most conservative agencies - the public school.

Within a broad and, sometimes, kaleidoscopic crusade for change, educational institutions found themselves the subject of a new and vigorous public scrutiny in British Columbia and elsewhere. Viewed in the headlights of a new era, British Columbia's public education system did not seem to be particularly democratic in its treatment of minorities, women, the handicapped, or the culturally diverse. Nor, indeed, did the historical precincts of school governance and management seem anything more than a gentlemen's club of professional administrators headed by a select

2 Margaret Ormsby, British Columbia: A History (Vancouver: Macmillan, 1958), 491 and 494. 
group of government mandarins in Victoria, in effect a "closedshop" to many others. As the 1970s began, even politicians conceded it was time to reorganize school policy-making along more democratic lines and to redistribute authority more widely throughout the educational system.

Even before the 1960s drew to a close, it was apparent the "old order" of school governance and administration in British Columbia was unravelling. Developments within government's education department, as well as social and political changes outside it, were disrupting the tranquillity that had long characterized the offices of the governments education bureau. Part of the disquietude was internal. By the late 1960s, the education department had become a mature and aging unit of government that had done little to renew itself since 1945. Complacency had become the price of success. In keeping with its past, senior staff continued to be "hand-picked" from "the field" by the provincial superintendent or deputy minister. Recruits brought to headquarters usually consisted of men with long administrative service, first as principals and, later, as inspectors and district superintendents.

Election of Dave Barrett's New Democratic Party (NDP) in 1972 only created further problems for the department. ${ }^{3}$ The new government's general distrust of the educational civil service was soon made evident when Minister of Education Eileen Dailly moved aside the departments senior staff in favour of outside appointments, including that of educational commissioner, John Bremer, a self-styled "egalitarian progressive" known for his "school without walls" experiment in Philadelphia. ${ }^{4}$ Dailly and the new government were clear in their intentions: they wished to overturn the old administrative order that centralized educational authority in the senior civil service and their agents in the field the district superintendents. Having promised throughout the campaign to decentralize educational government, Dailly sought ways to refocus the school system around "the teacher, the parent, and the child" instead of "the superintendent, the principal, and the teacher," as it was in the past. ${ }^{5}$ Dailly's dream of a status revolution was intended to break the grip of the educational past and, in keeping with the organizational fashion of the time, to

3 Stan Persky, Son of Socred (Vancouver: North Star Books, 1979), 138.

4 Thomas Fleming, "In the Imperial Age and After: Patterns of British Columbia School Leadership and the Institution of the Superintendency, 1849-1988," BC Studies 81 (Spring 1989): 50-76.

5 Ibid. 
redistribute power and authority more broadly so that those affected by decisions would have a hand in shaping them.

But from the beginning, Dailly was hounded by miscues and misadventures. Commissioner Bremer's seemingly aimless excursions around the province led to his public dismissal by the premier and cost the education minister a considerable loss of face. Dailly's establishment of a new "research and development division," headed by Stanley Knight, "to assist in the development of changes in education," proved equally disastrous. The "R and D" group's radical edge brought it into open conflict with the Department's old guard, forcing Dailly to suspend its operations. Shocked by her maladroitness, even the British Columbia Teachers' Federation (BCTF), which had campaigned vigorously for the NDP government, called for her resignation. ${ }^{6}$ According to historians Jean Barman and Neil Sutherland, "Mrs. Dailly seemed incapable of decisive action, and her tenure was characterized mostly by preparing for change rather than its implementation."7

Inside the newly renamed "Ministry of Education," tensions were aggravated further by volatile social and educational forces outside government. Beginning in the early 1970s, the provincial education office found itself whipsawed by assorted equity, access, and accountability issues raised, in part, by long-neglected and disenfranchised constituencies who challenged the fairness of school policies as they pertained to handicapped or "special needs" groups, children, women, and minorities. ${ }^{8}$ As educational government struggled to address these calls for broader, fairer, and more "inclusionary" school policies, new and no less vigorous constituencies were demanding other kinds of accountability to do with reducing educational costs and improving public education's academic performance. Government found itself defenceless against the double-edged sword of accountability, whether defined in terms of "inclusion" or fiscal responsibility.

Public alarm with the rising costs of schools was well founded. In the 24-year period from 1947 to 1971, school expenditures had

6 F. Henry Johnson, “A History of Public Education in British Columbia, Amended Manuscript," UBC Special Collections, 260.

7 Jean Barman and Neil Sutherland, "Royal Commission Retrospective," Policy Explorations 1, 1 (Winter 1988): 14.

8 Thomas Fleming, “'Our Boys in the Field': School Inspectors, Superintendents, and the Changing Character of School Leadership in British Columbia," in Schools in the West: Essays in Canadian Educational History, ed. Nancy M. Sheehan, J. D. Wilson, and David C. Jones (Calgary: Detselig, 1986), 300. 
increased 35-fold. ${ }^{9}$ Educational expenditures in 1971 were of a magnitude that surpassed the entire provincial budget only nine years earlier, representing nearly 29 per cent of total provincial expenditures compared to only 15 per cent twenty years before. ${ }^{10}$ At the same time, fears about declining scholastic scores in schools were making headlines in the popular press. They reflected a rising tide of public unease about the quality of public education and the efforts of dissatisfied parent and community groups to hold government more accountable for what was taking place in schools. Unmoved by promises of new programs and services, parents began to insist that educational government provide evidence about how well youngsters could read, write, and add. ${ }^{11}$

\section{Teacher Power}

Public restlessness with issues to do with inclusion and quality was more than matched by discontent within the ranks of teachers. From 1972 to 1996, the provincial government's chief adversary in schooling was the BCTF, an organization that functioned, more or less, as the government's "unofficial opposition" in all matters educational, regardless of which party was in power. During this time, the BCTF proved to be far more influential in shaping government educational policy than all other major provincial organizations interested in education, including the British Columbia School Trustees' Association (BCSTA), and the Association of British Columbia School Superintendents (ABCSS). ${ }^{12}$

Throughout the twentieth century's first half, the BCTF had generally worked co-operatively with government and enjoyed far greater influence within the education department than the trustees' organization, which was regarded as something of a nuisance by civil service professionals. ${ }^{13}$ Prominent Federation members such as John Lister, Harry Charlesworth, and Bernard Gillie maintained

9 British Columbia Department of Education, One Hundred Years (Victoria, British Columbia: Queen’s Printer, 1971), 90.

10 Ibid.

11 Thomas Fleming, "Accountability: Some Considerations of a Continuing Educational Dilemma,” The Journal of Educational Thought (April 1978): 28-36.

12 Later renamed the British Columbia School Superintendents' Association (BCSSA).

13 James London, "Lay Control in Public Education: The British Columbia School Trustees Association, 1905-1946," School Leadership: The British Columbia Experience, ed. Thomas Fleming (Mill Bay, B. C.: Bendall Books, 2001), 235. 
close contact with the Department of Education throughout their terms as Federation presidents or executive secretaries. Others, such as C.G. Brown, Colonel Johnny Burnett, Joe Phillipson, and R.B. Cox, enlisted as provincial school inspectors when their presidencies in the Federation ended. The equalization that UBC professor Max Cameron's 1946 consolidation plan imposed on the system, along with the fine-tunings of school finance formulas offered by the department's men, Harold Campbell and J.F.K. English, in the 1950s, settled many of the BCTF's long-standing concerns about teacher welfare and security and provided a platform for the Federation to widen its influence in other areas.

As the 1960s began, the Federation turned its hand, first, to enlarging teacher influence in curricular and instructional domains, and, later, to strengthening its influence in educational policymaking, including promotion of larger social justice issues. In 1967, J. Harley Robertson summed up his year as BCTF president by emphasizing a changing attitude in the Federation's membership: "Teachers have shown that they no longer wish to be cast in a submissive role in education. The growing militancy has led teachers directly to campaign on class size, to act politically, to use publicity in their areas of interest [and] to seek support for their educational demands." ${ }^{14}$ Such activities, of course, put the BCTF on a collision course with the Department of Education and with the Social Credit Government in general.

This new-found militancy was variously expressed. It was made manifest in B.C. Teacher editorials critical of the government's building program, as well as the teachers' 1969 "apple” campaign which first challenged funding levels and endorsed candidates in accord with the Federation's position. Angered by the BCTF's intrusion into provincial politics, Social Credit education minister Leslie Peterson introduced a legislative amendment in 1971 excusing teachers from automatic membership in the Federation. Although fewer than 500 of the province's 22,000 teachers revoked their membership as a result of this legislation, it signified the beginning of an educational "cold war" that intensified as the BCTF executive edged closer to political alignment with the NDP.

In the 1972 election, a Teachers' Political Action Committee (TPAC) was formed to raise funds to oppose the re-election of the Social Credit government, thereby circumventing the legal question

14 Johnson, "A History of Public Education in British Columbia, Amended Manuscript,” 259. 
about whether the BCTF's general revenues could be used to campaign against a political party. Thirty-two of the thirty-five candidates endorsed by TPAC won seats as the NDP administration began its "1,000-day" regime. The BCTF executive was by now firmly in the hands of militants, notably supporters of the "radical Marxist” Jim McFarlan, to use historian F. Henry Johnson's description, who was twice voted Federation president in the early 1970s. ${ }^{15}$ McFarlan and his group within the Federation believed schools should be used as instruments of social change, a view earlier espoused by American educational reconstructionists in the 1930s. McFarlan was not at all shy about exercising his political clout. In two instances - one about class size and one about Knight's dismissal as R and D chief - McFarlan called for Minister Dailly's resignation, marking the only two occasions in provincial school history when the Federation demanded a minister's removal.

Movement toward a more radical stance was further evident in the 1977 formation of the Teachers' Viewpoint, another splinter group within the BCTF, which sought to develop a "new kind of progressive caucus." " Fronted at times by Surrey teacher David Chudnovsky, the Teachers' Viewpoint group aspired to the same sort of labour solidarity that Rural Teachers' Federation (RTF) advocates had demanded in the 1930s and 1940s. As Chudnovsky argued: "It is essential that there be an organized group of B.C. teachers openly and consciously working to build a union with the right to strike - in other words beginning the task of uniting teachers with other workers." ${ }^{17}$ Naturally, Chudnovsky's teachers' union offered no place for principals or others who held "primarily management functions." ${ }^{18}$ This militancy spilled over into the BCTF executive. The Federation's three presidents from 1981 to 1987 - Larry Kuehn, Pat Clarke, and Elsie McMurphy - were all members of the Teachers' Viewpoint group, as were other executive officers. ${ }^{19}$

Despite divisions and friction inside the Federation, and public concerns regarding the influence that fringe and radical elements

\footnotetext{
15 Ibid., 260.

16 Seija Tyllinen, "The History of the Separation of Principals from the British Columbia Teachers' Federation” (M.A. thesis, UBC, 1988), 41.

17 Ibid.

18 Ibid., 42.

19 Ibid., 69. According to Tyllinen (85), McMurphy renounced her membership in the Teachers' Viewpoint group a few months before her third re-election as president in 1988-1989 in order to form an opposing group called "Teachers for a United Federation.”
} 
wielded over the membership, the BCTF, by and large, remained a cohesive political force and an able combatant for government. It had reached, by its own admission, its "full maturity" as a professional and political organization, ever mindful of the external and, sometimes, hostile environment in which it saw itself operating. ${ }^{20}$ Part of this was because of the organizational and political sophistication of the executive, the Federation's wealth and status as the province's largest educational organization, and the fact that its ranks virtually doubled from 22,000 to nearly 45,000 members between 1972 and 1996. Part of its new-found power was also attributable to its success in convincing parents and the public that "input measures" such as higher salaries for teachers, smaller class sizes, and other improvements in learning conditions were more salient and credible measures of educational quality than the standardized measurements of pupil performance that provincial authorities tried to introduce in the late 1970s and early 1980s.

The Federation was equally successful in persuading parents and the public that the most important educational outcomes to do with higher thinking, creativity, and love of learning defied measurement by standardized tests. Even when the Ministry developed clear and objective measures of district, school, and pupil performance in the early 1980s, it found itself compromised by circumstances beyond its control. Provincial officials were reluctant to publish management information and student performance data which illustrated wide variance in district-todistrict, as well as inter-district, educational outcomes lest parents and the public make the lack of system-wide equity and accountability even more difficult political issues. And so, data sets illustrative of the system's condition remained out of public view, open only to bureaucrats and their political masters inside provincial and local board offices. Like the engineer in Hamlet, "hoist with his own petard," the Ministry found itself impotent in waging war for the hearts and minds of British Columbians with weapons it built but dared not use. ${ }^{21}$

\footnotetext{
20 Ibid., 28.

21 In Hamlet, Act III, the word "petar" was likely the word first used. In today's common usage, "petard" seems to prevail.
} 


\section{Disconnecting Governance and Administration}

The NDP's election in 1972 also raised anew an older question about who should control school district leadership. This issue, which first surfaced in the early 1900s with the Vancouver board's demand for autonomy, was reborn in the early 1950s when the BCSTA proposed that control over senior administrative appointments in local schools should rest with district boards, not with the province. Since then, the BCSTA, as well as the BCTF, had forcefully expressed the idea of a decentralized system during Sperrin Chant's 1960 royal commission inquiry, arguing, essentially, that the restructuring that Cameron's one-man commission recommended in 1945 had changed the bases of power among districts but had done nothing to address power relationship between district boards and the province. ${ }^{22}$

Calls for changing the control of local school leadership were largely ignored by the province during W.A.C. Bennett's Social Credit regime in the 1950s and 1960s. The Department of Education and its political leadership were otherwise preoccupied, principally with designing a new post-secondary system. Nor was Bennett, an avowed centralist in behaviour, likely to have listened to his education advisors even if they had been moved to suggest such a change, which they were not. Bennett kept the Department of Education at arm's length as a rule, preferring to limit his association to brief annual meetings with Ed Espley, the Department's comptroller, during which time Bennett reputedly presented the educational civil service with annual budgets that sometimes bore little resemblance to estimates submitted through ministers. ${ }^{23}$ With Bennett's political passing, the local control issue made its way onto the tables of government for the first time in 1972, abetted by the NDP's commitment to relocate decision making "out there, among the people," as one senior civil servant of the day put it. ${ }^{24}$

In part, the local employment issue was also ignited by events inside the educational civil service itself. The department's field officers, the inspectors and, after 1958, the district superintendents, had long felt aggrieved over their low salaries. Again, this was an

22 British Columbia School Trustees’ Association, "Brief to the Royal Commission on Education," 1959, 28; British Columbia Teachers' Federation, "Brief to the Royal Commission on Education,” 1959, 31.

23 Interview with Ed Carlin, Vancouver, 18 Dec. 1984.

24 Interview with Jack Fleming, Saanich, British Columbia, 15 June 1995. 
historical issue raised first during Alexander Robinson's reign as school chief in the early years of the century and by the Provincial School Inspectors' Association in the 1930s and 1940s. ${ }^{25}$ Each time the complaint was similar and each time the issue remained unresolved. Inspectors resented the fact that high school principals around the province were routinely paid considerably more than either inspectors or superintendents, even though principalships were generally held to be less important offices in the province's educational hierarchy. School commissioners Putman and Weir and, later, Chant condemned this practice in 1925 and 1960 respectively, arguing that this financial anomaly had deleterious effects on recruiting the best people to the normal schools, the provincial inspectorate, and the superintendency.

The stumbling block was the civil service classification scale, or "salary tree," as it was more commonly known, where increments among "grades" were small and so tightly prescribed that even long-serving and powerful deputy ministers like S.J. Willis could not move the civil service commission to secure relief for his senior staff. ${ }^{26}$ As district-based principals' salaries increased more rapidly in the 1950s and 1960s, differences in compensation between principals and superintendents became more acute and professionally embarrassing for superintendents. One provincially paid superintendent disclosed that his job as chief education officer for a large urban district in the 1960s secured for him a rank of 57th on the district's salary scale. ${ }^{27}$

For many superintendents, salary was a proxy for status and respect. As experienced civil servants, inspectors and the district superintendents who superseded them had endured years of itinerancy and hardship. Their careers were often a patchwork of assignments resulting in a gypsy-like existence that took them from one end of the province to another, always at the department's call. At a moment's notice, they could be dispatched to manage a district hundreds of miles away or more. Moving meant uprooting families, selling houses, and changing children's schools. Oftimes these changes proved financially burdensome, especially when it came to purchasing homes in more expensive districts. Nevertheless, most persevered, sustained by the beliefs that, ultimately, "the

25 Provincial Archives of British Columbia (hereafter PABC), Alexander Robinson's correspondence with J.J. Ross, Edmonton, Alberta, 23 Oct. 1919, Superintendent of Education's Letterbooks, vol. 189, 9280.

26 S.N.F. Chant, J.E. Liersh, and R.P. Walrod, Report of the Royal Commission on Education (Victoria: Queen's Printer, 1960), 68-69.

27 Interview with Bill Lucas, Vancouver, 7 Dec. 1983. 
department would look after its men," and that loyalty and faithful service would be rewarded. ${ }^{28}$ However, as the 1960 s drew to a close, the long-festering salary issue seemed no closer to settlement than decades earlier and the government's education officers began to despair of the civil service and its unwillingness to address the inequity that so obviously existed. Even to the most committed, such intransigence seemed to signal a fundamental lack of regard on government's part.

Tensions over salary and respect were aggravated by other difficulties within the Department. Continued conflict between "old" and "new" factions in senior management led to a climate of uncertainty throughout the province's education bureau in the early 1970s. Before long, district superintendents were dividing themselves into camps "for" and "against" local employment. Legislation passed in 1974 allowing the province's largest districts to appoint their own superintendents proved a turning point in tipping the scales in favour of local employment. After half a dozen years of discussion and negotiation, the province capitulated and, in August 1980, legislation was introduced granting all provincial school districts the authority to appoint their own superintendents. Much like King John's signature on the Magna Carta, which recognized a changing England, provincial legislation allowing boards to appoint their own school leaders likewise ushered in a new age. From this time on, the province would maintain responsibility for the governance of schooling but would delegate responsibility for local school administration to others.

The historical significance of this event, not to mention its consequences, was missed by both sides. Few in educational government, or in local school administration, appreciated that the future would be remarkably different from the past. Disconnecting school governance and administration - two functions unified for more than 100 years - meant more than simply eliminating imperial administrative traditions. It bespoke a deep division, or disconnection, at the public system's core. On one hand, it meant a change in the allegiance of superintendents from provincial authorities to their new political masters on school boards. On the other, it meant superintendents were removed from government's inner circle and, thus, no longer privy to the political intelligence that government's field officers historically enjoyed. Above all, it marked what would prove to be the beginning of a new and 
adversarial chapter in school history. From now on, seventy-five districts, represented by their own educational standard bearers, would compete with each other - and struggle with senior government - for their share of what was fast becoming an inelastic provincial budget.

\section{Government Adrift}

The province's decision to grant local districts control over senior administrative appointments largely severed its relationship with the real world of schools and, in so doing, changed the organizational character of the Ministry of Education in several ways. First and foremost, it meant that provincial authorities had to devise new ways to govern the system without a tangible administrative presence. This they did by developing a new and different authority structure that had less to do with the individual expertise of government officers, or with government's symbolic role in leadership, and more to do with new policies and technical procedures designed to direct and monitor the system by remote control. $^{29}$ The new approach was a model of educational government based on laws and policies, rather than a model of "government by men," as the old colonial regime of school administration had been. ${ }^{30}$ As such, it was predicated far more on the tasks of measuring, evaluating, analyzing, rationalizing, and equalizing educational inputs and outputs than with understanding human elements of school management.

This change in view reflected the growing size, complexity, and cost of schooling at both provincial and local levels. As education grew to become an enormous industry in the 1970s, and as public demands for greater efficiency, equity, and accountability increased, government found itself with little choice but to adopt quantitative assessment strategies transforming other large organizations throughout North America at the time, and to apply these strategies in governing the system. The government's new approach was made manifest in various initiatives: to wit, establishing the provincial learning assessment program in 1976; introducing the core curriculum in 1977; reorganizing special programs branch in 1978; setting out budgetary incentive grants in 1979; implementing the fiscal restraint program in 1982, as well as

29 Fleming, "In the Imperial Age and After," 68.

30 Ibid., 71. 
developing the government's "Indicators of Management Performance" that same year; and, finally, reintroducing provincial exams in 1984. ${ }^{31}$ These policy and procedural developments outlined a portrait of a ministry that had come to see its role principally as that of evaluating, monitoring, and controlling what was being taught, what was being learned, and what was being spent. In other words, the provincial government had carved out for itself two key tasks of governance - defining what was essential in schooling and providing measures to illustrate the system's accountability. Although government's education bureau had always supervised such matters, it attempted to do so now through newly developed management information systems rather than through century-old face-to-face traditions of field inspection. However effective or efficient in practice, this new technocratic approach to educational governance was badly flawed in one important respect. As regulatory and bureaucratic supervision took the place of the visible and personal administration that the Ministry and its staff had long provided, there appeared to be a leadership vacuum at the top of the system.

Minister Brian Smith's 1980 educational tour of the province did little to alter this perception. Conceived as an attempt to fly the provincial colours, Smith's initiative marked the first of three government reform efforts in the 1980s to collect public and educational information on which to base a new mandate for the schools. ${ }^{32}$ Smith's tour, comprised of forty-one public forums, proved generally unsuccessful in establishing new directions for government or the schools, principally because of its lack of focus, its reliance on meagre amounts of anecdotal evidence, and its narrow interest in structural questions of dubious significance. To illustrate, Smith wanted to know, among other things: Could a case be made for middle schools? Community schools? What constituted the ideal size for secondary schools? And, should multiple entry points be made available to kindergarten youngsters?

The relevance of Smith's questions was difficult to understand, particularly to a school system assailed by rapidly rising costs, unprecedented political discord about school policy at provincial and local levels, public outcries for fiscal and performance

31 The clearest statement of the government's intention to curtail school costs by developing a new technically driven system of accountability can be seen in British Columbia Ministry of Education, "Indicators of Management Performance” (Victoria, British Columbia: Ministry of Education Data Services, 1982).

32 British Columbia Ministry of Education, A Report from the Minister (Victoria: Province of British Columbia, 1981). 
accountability from certain quarters, and, from others, assorted demands for new programs and services for women, handicapped children, Aboriginals, inner-city youngsters, immigrants, Englishas-a-Second-Language (ESL) learners, and French-speaking British Columbians. When Smith's “Apple” report was released in 1981 so named because of the symbolic red apple on its cover - it tackled neither the structural questions raised in public discussion nor addressed what schools should or should not do. The report's character was vague. About school structures, Smith simply indicated that "the Ministry will study the advantages and disadvantages of the various school organization patterns."33 About the scope of the school's responsibility, the report offered nothing but shop-worn platitudes about sharing responsibility between provincial and local governments, as well as among school and other community agencies. If Voltaire was correct in remarking that his literary rival Diderot mastered "the grand art of saying nothing” in 43 volumes, Smith's “Apple” report likely accomplished the same feat in only 183 pages.

Problems that Smith and subsequent education ministers faced in defining an appropriate mandate for provincial schools went far beyond the education portfolio to the foundations of modern government itself. The question of whether the school could serve effectively as both an educational and social agency was intertwined with deeper political and philosophical issues about the extent of state intervention in private life and whether government should serve to ensure the emergence of a providential state attending to human needs from "womb to tomb." By the late 1970s, however, the social and political philosophy of liberalism upon which Canadian and other Western governments had been premised for more than a century was losing considerable political currency at home and abroad. ${ }^{34}$ Beleaguered by three decades of public debt, and mindful of reduced levels of government in Great Britain, the United States, and New Zealand, federal authorities in Ottawa attempted to stem rising public sector costs through a “wage and price controls" program in 1978. Around the same time, critics in and outside government began to question liberalism's efficacy and called for a new and more limited role for government in various arenas of social life, including schools.

\footnotetext{
33 Ibid., 38.

34 Thomas Fleming, "Canadian School Policy in Liberal and Post-Liberal Eras: Historical Perspectives on the Changing Social Context of Schooling, 1846-1990," Journal of Education Policy 6, 2 (1991): 183-99.
} 
These events marked the beginning of an important philosophical transition in public education - a transition away from a view of schools as universal and providential agencies to one that saw schools as institutions more loosely structured and diverse in character. ${ }^{35}$ As I put it in 1993:

Gone is the confidence within government - and the public that the problems of schools, or those of society, can be corrected by larger infusions of public money into education. Gone is the optimism - certainly among senior policy makers - that this period of economic recession and restraint is but a temporary interruption to the normal flow of events and that, when the economy rebounds, it will be "business as usual." Gone, too, it seems, is the vast, unwritten, and long-lived public consensus that schooling should be predominantly statecontrolled, that the public school should be common to every child's life, and that public education is the most effective institutional cornerstone of democratic living. ${ }^{36}$

As this view emerged in the mid-1970s, the British Columbia Ministry of Education - and, indeed, other branches of government - found itself having to reconcile the liberal "input" model of public provision with an emerging neo-conservative or post-liberal view which favoured a more restrained approach to government's role in public and private life and much greater emphasis on measuring the "outputs" achieved by public spending. ${ }^{37}$ Reconciliation, however, was complicated. Throughout the twentieth century, both government and the education profession had defined progress exclusively in terms of "inputs.” Directing more money and resources to schools was generally held to produce "good" or "better" educational quality and performance. To schoolmen and schoolwomen of the post-World-War-II era - as well as the public at large - it was axiomatic that increased levels of educational support led directly to newer schools, more

\footnotetext{
35 Ibid.

36 Thomas Fleming, Review and Commentary on Schooling in Canada 1993: A Report to the UNESCO International Seminar on Curriculum and Decentralization (Santiago, Chile), 53.

37 Ibid., 193. Through sometimes labeled the "new conservatism," this phrase does not quite capture the complex sentiments electorates have sought to express in subscribing to this emerging view of government. It may be more accurate to describe the post-1975 philosophical and political era as "post-liberal," "pragmatic," or even an "age of existential government."
} 
extensive and richer educational programs, a more complete range of school services, more modern athletic and other facilities, and smaller class sizes. Such investments, it was generally assumed, were ultimately associated with better schools and higher pupil performance.

Nurtured in this orthodoxy, bureaucrats had difficulty imagining educational improvements in other terms, even when they learned that ambitious and expensive educational reform efforts in the U. S. during the late 1960s and early 1970s had generally failed to reach their objectives. Educational managers long accustomed to measuring success in larger staffs, bigger programs, an expanding list of "clients," and budgets that appreciated year after year, were ill-adapted to "keep score" in other ways or to rationalize a change in government perspective to countless "stakeholder" groups who had prompted government growth by lobbying for additional programs and services in the first place. People in and outside the system had come to believe in an ever-expanding universe of government provision. In other words, as government sought to shed itself of the responsibility for enlarging public services to secure progress and equity, it attempted to do so in a climate of social uncertainty in which older liberal ideas had yet to be discarded while the tenets of the new conservatism had yet to be embraced. Evidence of this ideological unease abounded in the popular press of the day, in policy-making journals, and in the committee rooms of government itself, where ministerial and inter-ministerial battles raged about the scope, cost, and purpose of government activity.

Making things even more complex for itself, the Ministry of Education sought to quell rising special-interest-group demands by adopting a new and confusing language of governance. Nothing had changed since the nineteenth century when the British North America Act (1867) - renamed the Constitution Act in 1982 placed responsibility for school governance firmly in the hands of provincial legislatures and their educational agencies. Despite this legislation's clarity, it became fashionable in governance and administrative circles of the post-1972 period for politicians, bureaucrats, professors, and special-interest groups to speak of concepts such as "decentralized control," "co-governance," "educational partnerships," and "stakeholder groups," as if such terms actually held legal meaning. This rhetoric was meant, of course, to reflect the anti-authoritarian and highly democratic mood of the time. It was also used in and around educational government as a social and political lubricant to "cool out" dissent through what 
organizationalists term “co-optation.” Its usage, however, backfired by giving rise to a mythology suggesting that school governance was a "shared" responsibility between provincial and local authorities, inflating local expectations for more widespread participation in the educational affairs of state, and bringing into question the province's legitimacy in acting alone as chief educational custodian at times of economic or social crisis.

Ambiguity about "who should govern what" clearly contributed to the educational conflicts that erupted as British Columbia entered the early 1980s. A recession in the province's basic resource industries greatly reduced provincial revenue while public sector costs, particularly in health care and education, continued to mushroom. By the late 1970s, school board expenditures in British Columbia were easily outstripping "Basic Education Program” (BEP) allowances, driving up school budgets and property taxes. On average, school board budgets increased 19 per cent province-wide in 1981 and school taxes rose 25 per cent province-wide over the previous year. In Vancouver, school taxes in 1981 were 40 per cent higher than the year before, leading to taxpayer protests and petitions to senior government for relief. Altogether in the five-year period from 1976 to 1981, public school costs rose from $\$ 900$ million to $\$ 1.6$ billion, an increase of nearly 80 per cent at a time when the provincial school population had declined by 32,000 pupils. By 1982, almost 20 per cent of British Columbia's total budget was being spent on schools. ${ }^{38}$

\section{Provincial Restraint and the School Wars}

Driven by a need to stem rising public sector costs, the provincial government convened a retreat for ministers and senior officials in January 1982 at Schooner Cove on Vancouver Island. A month later, Premier Bill Bennett announced his intention to pass the Public Service Restraint Act and, in March 1982, the Education Interim Finance Act, which allowed the province to set limits on school district budgets and removed boards' capacity to tax commercial property. Boards wishing to spend more than 110 per cent of their BEP would now have to secure the approval of local taxpayers in a referendum. Teachers, trustees, and government

38 Thomas Fleming, "Restraint, Reform, and Reallocation: A Brief Analysis of British Columbia Government Policies in Education, 1981-1984,” Education Canada (Spring 1985): 4-12. 
workers responded angrily to the restraint program. Layoffs of 400 and, later, 1,600 provincial employees led to a series of demonstrations numbering 20,000, 25,000, 40,000, and 60,000 protesters in the summer and autumn of 1983. During the next two years of what journalist Crawford Kilian called the "school wars," teachers expressed their discontent with spending cuts through job actions and a six-day strike in November 1983. ${ }^{39}$ Trustees first contested the legislation unsuccessfully in court and, later, refused compliance to provincial demands for lower budgets, a decision that led to the dismissal of the entire Vancouver board and the appointment of Allan Stables, an "official government trustee." Shortly after, the Cowichan board was also dismissed. All in all, thirty-five school districts that initially claimed they would resist the government's demands for reductions eventually submitted.

With the advent of restraint, the BCTF cast itself as the chief defender of the educational faith, pre-empting all others in its claim to speak on behalf of children and parents. Moreover, as the restraint program made provincial education officials - and, indeed, ministers of the day - educational pariahs, it was a relatively simple matter for the Federation to recite old truths and platitudes about the importance of increasing levels of educational spending, extending the school's social mandate into ESL programs, meals programs for inner-city children, and other interventions which generally endorsed the expansionist sentiments of earlier and more prosperous times.

Emboldened by post-1970s claims to a new-found professionalism, the BCTF had also begun to press school boards for better working conditions in the early 1980s and for greater measures of teacher autonomy. Both teacher "locals" and the Federation targeted reductions in teachers' workload as "a battle to be won.” Since 1946, when Vernon teachers sought freedom from pupil supervision chores during lunch-time, teachers had tried without much success to bargain about working conditions, only to be informed by boards that such things were non-negotiable. By the early 1980s, fewer than one-third of local associations enjoyed any form of duty-free lunch-break clauses in their contracts." ${ }^{40}$ As West

39 Crawford Kilian, School Wars: The Assault on B.C. Education (Vancouver: New Star Books, 1985).

40 Newsmagazine of the B.C. Teachers' Federation, “Teacher,” May 1988, 3. The 21 local associations that achieved some form of duty-free lunch hour agreements with their boards are: Fernie, Windermere, Castlegar, Arrow Lakes, Trail, Golden, North Thompson, Langley, Delta, Vancouver New Westminster, Maple Ridge, Howe Sound, Peace River North, Qualicum, Courtenay, Campbell River, Mission, Vancouver Island 
Vancouver Teachers’ Association president Kit Krieger noted: “A local bargaining survey showed that after salaries, workload was most important to teachers. Key specific items included reduced class size and duty-free lunch hours." ${ }^{41}$ These items, however, were the thin end of a much larger agenda that included: "firm class size limits"; "preparation time expressed as hours of instruction"; "full professional autonomy and professional control over educational change"; definition of "work year and the duration of the school day"; and "professional control over teaching." 42 Some local associations also demanded additional payment for teacher involvement in extra-curricular activities. A teachers' newsmagazine article advised that, to achieve a " 5.5 hour working day," teachers should eliminate homework assignments, "all coaching and refereeing” duties, sponsorship of school-award programs, "volunteer supervision," and committee service, as well as "fund-raising" and "social conscience" activities. ${ }^{43}$

The restraint program, although effective in capping educational spending, proved costly in other ways. As never before, it separated the Ministry of Education from educators in general, and teachers in particular, greatly diminishing the credibility of education ministers and their senior staff to portray themselves as stewards of public schooling. As the restraint program became depicted by the press - and by teachers - as something of a western morality play in which forces of darkness were pitted against forces of light, Victoria's provincial bureaucracy was increasingly criticized by teachers, administrators, and parents for its part in "the assault," as critics put it, "on public education."

The government's restraint program inadvertently opened a window of opportunity for the BCTF and local school trustees to make enormous political capital by positioning themselves as public education's chief crusaders, regardless of their own particular interests and motives. Public sector restraint, according to Kilian, also drove teachers farther into the bosom of the labour movement, something they had resisted since the 1940s:

Having been blooded in the province-wide strike, teachers could calmly contemplate the pros and cons of striking locally. In that respect, the teaching profession in B. C. had become

\footnotetext{
North, Creston-Kaslo and Stikine.

41 Ibid.

42 Ibid., 2, 6 (Feb./Mar. 1990): 4.

43 Ibid., 3, 7 (June 1991): 2.
} 
permanently more politicized, as it moved closer to the centre of the labour movement. Teachers had begun to see themselves less as aspiring professionals and more as workers, no longer kidding themselves that a university degree and a teaching certificate somehow elevated them above the ranks of the working class. If that was a development deplored by many British Columbians, they had only themselves to blame for it. ${ }^{44}$

At the restraint program's apogee in the mid-1980s, it seemed no educational official - either elected or appointed - was prepared to speak forthrightly on behalf of the province's schools or the youngsters who attended them. Ministry personnel, either silenced by their political masters or instructed by senior officials to stay off the political skyline, went to ground and, as a result, communication between the educational civil service and "the field" virtually ceased except for discussion of routine matters. ${ }^{45}$ With Ministry staff confined to Government Street bunkers, the immense educational ship-of-state appeared in effect to be without captain, crew, or sense of direction.

\section{Making Matters Worse: Legislative Changes, 1987}

While the BCTF and the provincial government battled like Titans in the heavens over control of provincial schools, British Columbia principals were involved in their own imbroglio with the BCTF executive and some of its members regarding their place as a specialist organization within the Federation, a subject of dispute since the 1987 Industrial Relations Act classified principals, viceprincipals, and supervisory staff as "senior management." 46 The

\footnotetext{
$44 \quad$ Kilian, School Wars, 97.

45 Interview with Alan Newberry, Calgary, Alberta, 27 Feb. 1987.

46 Lost in the separation of 1987 was a long-standing tradition older than the Federation itself of colleagueship between principals and teachers. Prior to the 1960s, principals had been among the most active and influential members of the Federation. Thirty-four of the 44 BCTF presidents before 1960 were school principals. Among the school principals to become Federation presidents were: John G. Lister (Vancouver Technical); Harry Charlesworth (Oaklands, Victoria); J.R. Pollock (South Park, Victoria); George Ferguson (Chemainus); G.W. Clark (Grand Forks); W.H. Morrow (Lord Byng, Vancouver); T.W. Woodhead (Model Elementary, Vancouver); Ira Dilworth (Victoria High); C.G. Brown (Burnaby South); C.L. Thorber (Tecumseh, Vancouver); J.R. Mitchell (Vancouver West High School); R.P. Steeves (General Gordon, Vancouver); J.N. Burnett (Aberdeen, Vancouver); J.M. Thomas (Mount View, Victoria); W.R. McDougall (Vancouver North High); A.T. Alsbury (King George High, Vancouver); L.B. Stibbs (Kelowna Junior High); F.J. McRae (General
} 
November 1983 teachers' strike and subsequent job actions, as well as lay-offs of about 2,000 teachers in the wake of restraint, had aggravated tensions between the British Columbia Principals' and Vice-Principals' Association (BCPVPA) and teachers in general. Principals themselves were torn by the 1983 strike. Some crossed the picket lines and others sided with the teachers and refused to staff the schools. Seija Tyllinen's 1988 study of the BCPVPA's separation from the Federation reports a "stubbornness on both sides" and concludes that "the promulgation of the Teaching Profession Act may have simply accelerated the process of separation" already under way. ${ }^{47}$

Feeling increasingly marginalized and pressed to silence by their compatriots inside the Federation, principals' association executives began to meet privately in the mid-1980s with education ministers Hewitt and, later, Brummet, to explore their options. Meanwhile, inside Vander Zalm's Social Credit government, cabinet members were wrestling with an important conundrum. The BCTF had decided to launch a test case concerning the government's restriction on salaries under the compensation stabilization program, catching the provincial government unprepared. And, as the Federation's case took shape, the government grew less inclined to contest it.

Cabinet finally convinced itself that passage of the "right legislation" could solve two problems. By granting teachers control of their own professional development through creation of a teachers' college - something teachers had called for since the 1950 s - their public voice might become more professional in tone, like colleges of medicine and law, and thus more amenable to government. A “college of teachers," the cabinet surmised, might also accentuate divisions between "professional" and "union" perspectives long in a state of tension among the membership, thereby allowing the moderate majority of teachers to prevail over the Federation's radical and militant elements. The government's reasoning, though flawed, was transparent. Such legislation might divide the BCTF and undermine its power. Introducing additional

Brock, Vancouver); Bernard Gillie (Willows, Victoria); F.P. Lightbody (Tecumseh, Vancouver); T.M. Chalmers (McPherson Park, Burnaby); H.D. Dee (Victoria High); D.G. Chamberlain (Rossland); John Prior (Kensington, Burnaby); R.R. Smith (Sir Matthew Begbie, Vancouver); W.V. Allester (Duncan); Hilda Cryderman (Coldstream); Joe Phillipson (Williams Lake); I.D. Body (Seymour, Vancouver); H. N. Parrott (Dunsmuir Junior Secondary, Sooke); R.B. Cox (Prince Margaret, Penticton); and W. Janzen (Erma Stevenson, Surrey).

47 Tyllinen, "The History of the Separation," iii. 
legislation to separate principals from teachers, this reasoning further held, could shore up management's control of the schools by defining principals and vice-principals exclusively as officers of the board. ${ }^{48}$ The BCTF's Al Cornes portrayed the legislation as a "long shot" where government probably thought "Let's give the $* * * * * * *$ what they want, but let's throw a cog in the works, too."49 In any event, cabinet's estimate of the legislation's impact likely failed to factor in the profound distrust with which teachers held the Social Credit government in the wake of the bitterly remembered - and contested - public sector restraint program. By January 1988, 97 per cent of teachers had rejoined the BCTF. ${ }^{50}$

Interestingly, the two pieces of legislation, which would cast a far longer shadow across schools than ever imagined, were crafted in law offices outside the educational civil service. Educational officers in the Ministry of Education, including John Walsh, who headed the government's legislative and policy section, did not see the government's proposed bills until one hour before their release and at no time were given an opportunity to review or comment on the efficacy of the legislation. ${ }^{51}$ This event, in itself, amply signaled that the civil service's historical influence in school policy-making was broken and that control had passed over to the political domain. More than this, these legislative enactments ushered in a new and turbulent era of labour relations in schools that separated principals from teachers, made principals exiles in their own schools, and challenged the nature of administrative authority - this time at the school level.

\section{Diffusion and Ambiguity Within}

Part of the governance problem the Ministry of Education faced in the 1970s and 1980s was the increasingly diffuse character of the ministry itself. In 1972, when the NDP assumed the government's reins, the Department of Education was still a small and relatively flat organization headed by a deputy minister, six modestly supported divisional superintendents, and fourteen "special officials." With clerical staff, and the fifty-nine district superintendents who worked outside headquarters, the entire civil

Interview with James Carter, Vancouver, 9 May 1998.

Quoted in Tyllinen, "The History of the Separation,” 87.

Ibid.

Interview with Don Smyth, Sidney, British Columbia, 15 Aug. 2001. 
service complement, numbering only 136, was responsible for presiding over the governance and administration of 1,515 schools, four universities, and ten community colleges. ${ }^{52}$ In the postimperial years from 1972 to 1979, as the department's status was raised to that of a ministry, its staff grew from 136 to 598 members, with an accompanying five-fold increase in budget, illustrating that the chief characteristic of post-colonial regimes everywhere, as a British civil servant ironically observed in the 1940s, was to produce "more government instead of good government." ${ }^{33}$ Growth in Ministry ranks, however, did not last long. The Socred government's restraint program shrank the size of the Ministry from 780 to 435 staff from the early to mid-1980s. By this time, the Ministry no longer counted the fifty-nine locally employed superintendents on its roster, nor included the post-secondary branch, which had become a separate ministry.

The growing ambiguity of purpose within educational government between 1972 and 1992 can be illustrated in the bureaucratic growth that took place. In 1972, the education office's functions were confined to six branches - administrative services, field services, instructional services, post-secondary services, special services, and technical-vocational services. In 1992, the Ministry, stripped of district superintendents and the postsecondary side, was divided into twenty-nine different "branches and functions," principally to handle emerging demands for special programs and services. ${ }^{54}$ Among the panoply of new offices was the Aboriginal education branch, the business immigration branch, the immigration policy branch, the independent schools branch, the information services branch, the languages and multicultural programs branch, the gender equity and women's programs unit, and the planning and corporate research branch.

Multiplication of government programs and services compounded the ever-difficult task of governing the K-12 system by enlarging the task of managing the education ministry itself. Even by the mid-1980s as these new divisions and special branches were evolving, it had become a complex undertaking for senior officials to oversee the activities and purposes of the Ministry's various sub-units, much less to co-ordinate their initiatives or to

52 British Columbia, Annual Report of the Public Schools 1972-1973 (Victoria: Queen's Printer) (hereafter ARPS), D15-D87.

53 British Columbia Department of Education, "Estimates of Expenditures for the Fiscal Year Ending March 1971”; British Columbia Ministry of Education, Science, and Technology, "Estimates of Expenditure, 1979/80."

54 ARPS 1991-1992, 113-15. 
understand what they were actually doing or why they were doing it. The growing organizational complexity at the provincial level paralleled similar developments within large district systems in Vancouver and Victoria, leading parents and the public to wonder, "Who, if anyone, is in charge of public schooling?"55 In short, growth in educational government's size and scope after 1972, which reflected a national trend, obscured the locus of authority in public education and made it difficult to know who was responsible for what.

\section{Discontinuity}

Adding to public confusion about school leadership were numerous personnel changes at political and senior civil service levels during the 1980s and 1990s. Such changes stood in marked contrast to the continuity that historically had characterized British Columbia's education office. During the first eighty-one years of public school history, six senior civil servants presided over educational affairs as provincial superintendents of education or, after 1931, as deputy ministers. ${ }^{56}$ Taking a longer perspective, only twelve superintendents or deputies administered the system during the province's first 114 years. ${ }^{57}$ By the 1980s, however, both the deputy's and the minister's office were becoming organizational carousels in which few elected or appointed officials held seats for long. In the seven-year period between 1989 and 1996, seven deputies attempted to steer the helm of educational government. A deputy-a-year hardly constituted a model of stable leadership by

55 See, for example, Jeffrey Simpson, "No time to waste in restoring common sense to our education system," The Globe and Mail, 15 May 1991, A16; and Jeffrey Simpson, "Never mind input variables - what Canada needs is rebellion," The Globe and Mail, 16 Dec. 1992, A20. The debate, as captured by the press, is somewhat overdrawn and reads at times like a modern morality play. To be sure, liberal or progressive views about schooling are widely expressed throughout the education profession; still, few recent articles on education note that many parents favour childcentred systems of schooling over those of a more traditional character. Likewise, the press typically attributes conservative views to those in business and industry which, again, may not be altogether accurate. Within educational ranks across the country can be found numerous teachers and principals who remain committed to formal and traditional approaches to schooling. However, in broad terms, the press is generally correct in arguing that those inside and those outside schools hold fundamentally different agendas for schools and about what is essential in education.

56 Department of Education, One Hundred Years, 96-97. The provincial superintendent's position was merged with that of the deputy minister in 1931.

57 Ibid. 
any standard. ${ }^{58}$ Moreover, between 1980 and 1996, eleven ministers held the education portfolio and, by the early 1990s, the education minister's term also averaged only about a year - a period far too brief to accomplish anything. ${ }^{59}$

Discontinuity at the top, coupled with major ministry restructurings every two years and episodic downsizings, led naturally to a climate of tentativeness, if not paralysis, throughout the provincial school bureaucracy. Small wonder that the Ministry seemed lost and in a perpetual state of searching for its own identity and mission, especially as administrative positions once held by educators were restaffed with individuals who knew government and management but nothing about schools or education. Small wonder, also, that Ministry officials lacked morale and purpose, or that "the vision thing," as former U.S. President George Bush inelegantly termed it, was so evidently missing in the decades after 1972.

Things became so turbulent at one point in the early 1990s that the NDP cabinet installed its own "official trustee" to oversee dayto-day educational affairs and the Ministry's compliance with cabinet's political agenda. This was a clear signal of education's new "political" importance as well as a change in the ownership of public education. One hundred years of "educational government" by civil servants had given way to a "government of education" by premiers' offices, cabinets, and education ministers all too conscious that schooling had become too large a public investment and too large a political issue to be consigned to the care of civil servants, however expert their credentials might be in its understanding, organization, and control. The movement by politicians to strip away the authority traditionally held by senior educational civil servants inside government was paralleled outside by a movement on the part of teachers, trustees, parents, and others to wrestle educational control of schools and school districts from principals, superintendents, and other school officials.

For better or worse, a century of professional control over public education in and outside government corridors was ending as the 1990s began and a new, more political, and deconstructed form of authority was beginning to emerge. Within this new

58 The deputy ministers included Sandy Peel, Wayne Desharnais, Valerie Mitchell, Cynthia Morton, Don Wright, Paul Pallan (Acting), and Don Avison.

59 British Columbia ministers of education in the 1980s and 1990s included: Brian Smith, Bill Vander Zalm, Jack Heinrich, James Hewitt, Tony Brummett, Stan Hagen, Anita Hagen, Art Charbonneau, Joy MacPhail, Paul Ramsey, Moe Sihota, Paul Ramsey, Gordon Wilson, Penny Priddy, and Joy MacPhail. 
context, and despite its complement of able professionals, the education ministry was reduced to three tasks - serving as a paymaster's office issuing cheques to keep the system going, a firefighting brigade dispatched to quell the crisis of the day, or, increasingly after 1988, a cheerleading squad for the minister's latest initiative. Inadvertently, the Ministry of Education had compromised its historical role as the sentry that monitored the state and performance of the schools by allowing itself to become a participant in delivering and advocating certain school programs and services - two things it had never done in over 120 years of operations.

The quarter of a century between 1972 and 1996 witnessed the end of the Imperial Age of school administration in British Columbia. The historical pattern of strong central control which had directed the course of provincial schooling for a century was beginning to unravel even before the 1960s were over, prompted in part by a malaise inside educational government and by new forces in and outside schools. Although provincial authorities entered the 1970s still confident in their capacity to control and direct public education, the Ministry of Education found itself before the decade ended, like Napoleon's army retreating from Moscow, bewildered by an unfamiliar landscape and harried on all sides by adversaries who seemed to materialize from nowhere, each with its own special brief for provincial schools. By the 1980s, the province's education bureaucracy, once the dominant and solitary voice in school affairs, was obliged to compete on the public policy stage with a chorus of others eager to contest the province's right to speak on behalf of children. By the mid-1990s, the rising power of the teachers' Federation, increasing parental and public demands for participation in educational decisions, and the Ministry of Education's ambiguity about its own purpose had all served, in various ways, to reduce the province's leadership in public education. 